\title{
Listening, really listening: a response to Graafland, Binmore and Ferber on The Bourgeois Virtues
}

\author{
Deirdre McCloskey* \\ University of Illinois at Chicago, USA; University of the Free State, South Africa, Academia Vitae, \\ Deventer, The Netherlands
}

We have three reviews here, one respectful and insightful, one amused and silly, and one angry and foolish. Professor Graafland, an economist and theologian who holds a chair in philosophy at Tilburg University in the Netherlands, is the one among the three who has troubled to understand the book. You know someone has understood your position when you can agree with his characterization of it. Let me start, then, with Professor Graafland's thoughtful and thought-provoking review. I leave my attempts to make sense of the silly and angry reviews to the end, so that you can more easily truncate your reading. You will see, I think, that cooperative games are better than non-cooperative games, and better advance our science.

Graafland makes a good point in objecting that I view the virtue of humility rather differently from the way Jesus did in the Sermon on the Mount. I speak of humility as attending to what others say - rather than being modest. ${ }^{1}$ Graafland himself exercises my attending-to definition. And my definition is not so far from that of St Thomas, or of C.S. Lewis.

I can also agree with Graafland that I did not in the book succeed 'in showing that the inverse impact of capitalism on virtues is as positive', as I wanted to claim. I offered a few arguments, some of them at length, but I do not expect my revival of the doux commerce thesis of Voltaire and Hume and Smith to convert everyone so easily. I have almost finished a second volume in the five I plan of an apology for the bourgeois life, Bourgeois Deeds: How Values Made the Modern World. It contains more arguments for and against the claim that the impact of capitalism on virtues in positive. It's available on my website (deirdremccloskey.org). And I have in hand a good deal of Volume 3, Bourgeois Rhetorics: How Language Works in Capitalism, which will be up on the website soon. Maybe those will help, with the two other tomes to follow (five, I say, and a popular summary on top of them: God help you, and me). Meanwhile I was amused to find in David Landes' recent Dynasties: Fortune and Misfortune in the World's Great Family Businesses (2006) a suggestive analysis of why bankers like the Baring family become so very proud and aristocratic: 'banking is bad for bankers' character. It is quite one thing to have to go out into the marketplace and solicit customers [which I claim is good for humility], and quite another to let the customers come and solicit your help and favor. The first pattern encourages businessmen to be polite and considerate; the second promotes arrogance and condescension', which Landes then illustrates at length in the Barings. ${ }^{2}$ Pride is a sin in business as in scholarship.

\footnotetext{
*Email: deirdrez@vic.edu 
And I also agree with Graafland's comment that there are various forms of capitalism, and that my discussion so far is nothing like adequately nuanced on that score. He is correct for example that capitalism c. 1776 was different in many ways from capitalism c. 2008 , and that 'the types of virtues that make these types of capitalism function well may differ'. How exactly and how much remains to be seen. Graafland would agree that how different is different is a delicate scientific judgment. For example, it's a relevant but probably not a decisive difference that we have faxes and email, while the people of 1776 did not. The rise of the corporate form, and the larger and bureaucratic scale of much of modern business, is surely important, but one cannot merely assume that such changes make for radically different systems of virtues. Maybe they do, maybe not. Let's see.

I also agree that nowadays Finnish capitalism or Japanese capitalism do not correspond exactly to a regime of laissez faire. On the other hand I would argue - and I think Graafland would agree, with reservations - that a society is to be desired in which voluntary exchange is accorded honor and a leading place, minimizing physical coercion. Such a society will need private property to make exchange meaningful - and in order to get, as Graafland wisely observes, quoting Lewis, the non-Hell that scarcity provides.

$\mathrm{He}$ and I disagree a little on what virtues and vices capitalism causes. It is not quite my unsupported 'opinion' that capitalism fosters cooperation. It is my considered judgment, argued at some length, with many supports from others who have considered the matter with an open mind (the economist Frank Knight, for example - perhaps not such a good example of an 'open mind'! - and numerous economic sociologists). But Graafland is right that not much research has been done on how and whether capitalism is good or bad for virtues, and how much. The finding of Henrich et al. (2004) that non-commercial societies are less likely to cooperate in games is suggestive. But there's not yet a great deal of evidence one way or the other.

The reason the research has not been done, I think, is that for about three centuries in the West (the Easterners are more sensible) we have viewed behavior as being divided into prudence (self-interest, rationality) and, by contrast with such prudence, Virtue. The division involves two mistakes. Prudence is a virtue, as I argue in the book, and as every virtue ethicist up to and including Adam Smith affirmed. ${ }^{3}$ Therefore self-interest is not to be set against Virtue as though self-interest was to be defined out of the virtues. If it is accompanied by the other virtues, self-interest is no sin. And Virtue is properly viewed as no one thing, such as Justice or Benevolence, but the named and plural and non-fungible virtues, including Prudence, Temperance, Justice, Courage, Love, Faith and Hope. Graafland agrees.

The one aspect of the book that Graafland misses is easy to miss, because I am rather confused about it myself. I want to argue that capitalism does in fact depend on and does encourage some virtues - and, alas, some vices, too. This is what Graafland takes the book to be about, as it is in good part.

But I also want to make the ethical point that capitalism should be better. An economist with a childish theory of ethics would call my point 'normative'. In particular I want to argue, and do so at great length in The Bourgeois Virtues and will argue at even greater length in Bourgeois Rhetorics, against the view of some of my friends on the right that 'greed is good'. And so I agree with some of my friends on the left, including Graafland, that a society infused with more virtues - a society in which we cease wrongly believing that game theory or the Revolution will alone suffice (without all that preaching about ethics) - would be better, and is to be recommended.

That is, I am being a scientist and at the same time - or at any rate in the same book what the economist with the childish theory of ethics, and a naïve anti-clericalism to boot, 
would call a 'preacher'. Therefore I would for example quite agree with Graafland that Americans work too many hours, worshipping as a sort of idolatry The Job or My Brilliant Career. And I agree that Christian or other solidarity is to be encouraged - admitting that like many traditional versions of the virtues it has a negative side, in the Dutch 'pillars' for example, which segregated Catholics from Protestants, socialists from Jews, and made it easy, in combination with the longstanding Dutch trust in the state, for the Germans to find and murder two-thirds of the Dutch Jews. I do not agree with the notion that trust in general has declined. But that is a factual matter to be determined by more serious empirical work than has so far been done by anyone, and certainly me.

We do more sharply disagree that 'the goal of virtues is just this: to become happy'. The Greek word that started the discussion, eudaimonia, is indeed sometimes translated erroneously as 'happiness', which then slides over to the pot-of-pleasure definition favored by modern utilitarians. A well-fed cat sitting on the window sill in the afternoon sun would report to a happiness-questionnaire scientist that she was happy, being at 9 on a scale of 10 (reserving 10 for sexual intercourse). But we are not cats - though I would be the last to deny that a cat-like 'happiness' from time to time is an element of a full life. Baskin-Robbins.

One would have thought that more economists, though, would be familiar with the Experience-Machine example that Robert Nozick devised in 1974 (I discuss it in The Bourgeois Virtues, pp. 124-125). 'Superduper neuropsychologists', wrote Nozick, 'would stimulate your brain so that you would think and feel' any life you want. ${ }^{4}$ Then you would die. 'Would you plug in?' No, of course not. You are you. You have an identity (faith) and projects (hope) and loyalties (love). Being Queen Elizabeth I would be great fun, the fun we get from a novel or a history about her reign, or a TV series starring Helen Mirren. But in a novel or TV series we do not have to give up being ourselves, and won't. Nozick's argument devastates any version of utilitarianism that does not have a serious theory of identity (faith, hope, love). The experiment shows, as Nozick put it elsewhere, that 'we are not empty containers or buckets to be stuffed with good things'.5

The better translation of Plato's and Aristotle's eudaimonia is 'fulfilled' or 'flourishing' or close to literally (though having then anachronistic Judeo-Christian overtones) 'blessed', since the word literally means 'having good spirits attending one'. Doubtless, if she was lucky enough in 1800 to miss smallpox and starvation, Burns' impoverished Scottish nut-brown maiden, 'Her eye so mildly beaming/ Her look so frank and free,' equaled in 'happiness' defined in the pot-of-pleasure sense the average person on the streets of Glasgow nowadays. That is what recent research on so-called happiness claims, quite plausibly. Nonetheless the modern Glaswegian has gigantically greater scope. She can do 100 times more of some things, leading a fuller life - fuller in travel, education, ease of life, ease of listening to 'The Nut-Brown Maiden' sung in English and Gaelic on the internet. 'Happiness' viewed as self-reported mood is not the point of a fully human life. Therefore I think it obvious that modern economic growth has greatly improved modern life, and made people better as much as better off. Some people don't get it, true, and watch TV for six hours a day and eat Frittos by the bagful. Therefore let us preach to them.

Graafland and I disagree most sharply that 'capitalism does not work optimally without a strong government'. The little word that makes his assertion sound plausible is 'optimally'. Since A.C. Pigou and Paul Samuelson spoke out loud and bold every externality or inequality is to be made 'optimal' by regulations exercised by saintly and all-wise bureaucrats. The government is to step in, for example, and 'stimulate true 
stewardship' of the environment. See a problem in society? Give the government more power, and call on it to Do Something About It.

May I suggest gently to Graafland and my very numerous center-left friends who believe such notions to consider in the bowels of Christ that they may be mistaken. The depletion of virtues by markets that Graafland quotes Albert Hirschman as worrying about is paralleled (and I think Albert, who fought in the Resistance against Hitler's version of strong government, would agree) by a depletion precisely from 'strong government'. Government regulation in most countries normally does not 'create a level playing field that benefits the most virtuous actors'. I wish it did. That would be wonderful, a little like the better deal for poor people that's supposed to arise merely by Congress passing a higher minimum wage. That would be a magic of which we should try to get as much as we can. For Lord's sake, set the minimum wage at \$200 an hour. Level the playing fields. Get a strong government and have it second-guess every decision by the capitalists, or by you.

I am writing in South Africa in May of 2008, and am reading Andrew Feinstein's distressing book about the ethical-governmental corruption of the African National Congress under Thabo Mbeki (Mbeki, by the way, holds an MA in economics from Sussex). Feinstein was a white, Jewish, ANC member of Parliament for seven years. 'Mbeki was placing his own, centralizing, technocratic stamp on [the ANC] ... [It] included the Presidency's active involvement ... of every area ... The emergence of a small clique ... usurped the place of collective debate within the ANC'. The result in the case of AIDS - there's an externality for you - was 'the abandonment of scientific principles', in sharp contrast to the success of Uganda in controlling the epidemic. Mbeki's 'own insecurity leads him to personalize criticism and demonize those who disagree with him [and what government has avoided that?], seen most obviously in his virulent reaction to Mandela and Tutu's polite and reasoned opposition to his view on AIDS'. ${ }^{6}$ Writes Professor Graafland here, 'basic positive rights [to distributive justice] should be guaranteed by the state'. They won't if the state is Mbeki's. Change the government? Sure, sure, if you can. Good luck. Better: make governments small, by preaching for smallness, and not riding the back of the Strong Government tiger.

I can understand why Graafland worries. He wants to guarantee distributive justice and environmental preservation and Christian solidarity. So do I. But the only guarantor Graafland can think of is strong government. He lives in the Netherlands and thinks of governments as honest regulators of a Tinbergian social engine. (But remember the local authorities handing over addresses of Jews to the Germans). And so he wants laws and regulations and compulsory social redistributions. But that is a Dutch lawyer's solution, not a South African economist's (except Mbeki!) or an American theologian's. Strong governments don't work very well in most parts of the world, and haven't in most of history. I am very willing to use the courts and the press to support laws against lynching and laws in favor of the right to vote. But I'm not willing to reach reflexively for my gun, calling on a strong government every time someone pollutes a stream or every time I see a poor person on the street.

I say rather, render unto Caesar what is Caesar's, and unto God what is God's. Guarantees here below are not available in the free-will, non-Edenic world God has arranged for us. We can try to persuade each other to ethical behavior. In my book I preach so. But I draw the line at massive violence against others, the sort a society needs, and anyway gets, if it carries out too many lawyerly guarantees.

But I thank Professor Graafland for his insightful reading. If you don't want to read all 500 pages of my arguments (shame on you), you can take Graafland's few pages as a pretty good short guide. 
Ken Binmore's review is amused and silly. Binmore proudly declares that he 'tries to stay within the boundaries of science', whereas I, he complains, recognize 'no boundaries at all'. One wonders why recognizing boundaries is such a grand idea. Surely we should seek enlightenment where it is to be found, not only under the lamp-post of rational choice theory or in the cultural clichés that an economist has command of who has neglected his self-education in the humanities. A methodology of demarcation would outlaw interdisciplinary inquiry. Surely intellectual free trade is a better idea?

Binmore does not seem to realize that 'science' as he defines it is a specifically English usage, arriving only in the middle of the nineteenth century. In all other languages, and in English before the quarrels over chairs in chemistry at Oxbridge a century and a half ago, 'science' means 'systematic inquiry'. Look it up in the Oxford English Dictionary. And so Binmore offers such gems of systematic literary inquiry as that style and substance are obviously completely distinct, or that 'good poetry isn't constrained by reason or facts'. I guess we can expect no better from someone who believes he should check his intelligence at the door of Art. His master demarcation is Art vs. Science. It's a pretty silly one. I wish he would read The Rhetoric of Economics, and think again.

As to politics, Binmore and I agree more than he thinks. Wanting health insurance for everyone, as I do, does not involve atheism (which he brings up: he is obsessed with my Christianity). It is perfectly consistent with a smaller government. And he and I and Professor Graafland agree that inequality is bad. If Binmore would read some economic history (apparently denied to someone who stays within the bounds of Science) he would know that inequality fluctuates over long periods, and that greater inequality recently is by no means confined to the lands of Reagan and Thatcher. There's no reason to think inequality will not revert to trend. The long trend under capitalism has been towards more and more equality of real comfort.

Binmore's argument that the virtues of unregulated markets rely 'on the highly unrealistic premise that all markets are perfectly competitive' is a mathematician's idea of economic science, not a physicist's or a historian's. I too believed it when I was an undergraduate, when I thought that economic science was about existence theorems. In graduate school I finally realized that we need to know, every time, how much 'perfection' is required. Theorems won't tell us. Boundary-less inquiry into facts infused with economic ideas will.

And the main point about the politics is that the 'we' who will regulate the 'certain industries' is after all a collection of human beings. Binmore wants the government to 'curb the greed' of monopolists. Like Graafland, he offers no thoughts on how we are to curb the greed of the politicians assigned in a regime with a very large government (Graafland's 'strong government') to curb the greed of the monopolists. Who will guard the guardians?

Binmore does not appear to realize that it is accepted on the left and right in economic science that government itself is the source of the more serious and permanent monopolies (see for example the splendid old book by the Marxist historian Gabriel Kolko (1965) on the Interstate Commerce Commission). Consider the long-lived monopolies of television in France and South Africa and many other countries - which, amazingly, always take the strong government's line in their political coverage. I'm shocked, simply shocked. A 'monopoly' that arises instead from, say, WalMart offering goods at 30\% lower than what its competitors can manage is not obviously something our political masters should concern themselves with. And if they do, their intervention is not likely to be for the common good. 
To support his contention that I am careless with facts Binmore takes a sample of four claims. (He starts off unpromisingly by doubting Robert Burton's claim that Socrates was gay and alcoholic, which no one could doubt who had read the Symposium, or had studied Greek, or was acquainted with the history of Greece. I guess such knowledge is not permitted to someone who 'sticks to science'.)

(1) Binmore says that Bayle was not an atheist. As is his custom he offers no evidence. But Binmore is here half correct. Bayle was indeed a Christian - though for the late seventeenth century a very, very progressive one. His Dictionnaire of 1697 was a great support for deists like Voltaire, and atheists like Hume. The book, which is filled with passages leading to doubt, was 'the arsenal of the Enlightenment', which had of course an important atheistic side. A case can be made', writes Thomas Lennon in the Stanford Encyclopedia of Philosophy, citing a book by Gianluca Mori in 1999 making just such a case, 'that the logic of Bayle's various positions on toleration, evil, truth, substance and accident, lead ineluctably to atheism'.

(2) Binmore says that Hume (who - we are informed - was 'great': thanks for setting us straight, Ken) did not sneer or laugh at religion. I yield to no one in admiration for the Sainted David. But I do not know how else to classify except as sneering and laughing Hume's characterizing of piety and purity as 'monkish virtues'. 'Celibacy, fasting, penance, mortification, self-denial, humility, silence, solitude, and the whole train of monkish virtues ... A gloomy, hare-brained enthusiast, after his death, may have a place in the calendar, but will scarcely ever be admitted, when alive, into intimacy and society, except by those who are as delirious and dismal as himself' (Enquiry Concerning the Principles of Morals, §9, ๆ3). Hume's is an ill-informed view of the life of monks and nuns, but anyway it is surely sneering and laughing. True, sneering and laughing at Catholics was usual in post-Knox Scotland, and in some circles still is. As the philosopher Dallas Willard remarked to the meeting of the Hume Society in 2003 ,

One should not forget that David Hume is a Scotsman, and that Scotland was in his time still heir to the Protestant Reformation to an extent few other places on earth have ever been. The passage on the monkish 'virtues' - that is, on the practices listed (not, of course, self-denial and humility) - could have come straight from the tongue or pen of Martin Luther, John Calvin or John Knox, and very similar passages actually did so come. Of course their reasons were quite different from Hume's, but because of them scorn for the 'monkish' could be counted on in Hume's context. It was a part of his 'common life.' So he doesn't have to be careful in the manner that was his admirable custom.

(3) Binmore says that rational contractualism in the style of Hobbes can't be shown rigorously to be impossible. I do not know how else to understand other than as just such a demonstration the unraveling of finite non-cooperative games, the Folk Theorem for infinite games, the now enormous body of experimental and historical findings that Max $U$ behavior is not a good description of human behavior - not useless for every purpose, understand, but nothing like adequate for many, such as marriage, politics, science, and a good deal of capitalism. Perhaps Binmore means by 'rigor' a proof that starts by assuming that contractualism is possible and then concludes that ... contractualism is possible. His professional indignation when I venture tangentially for this volume into game theory is not supported by anything resembling arguments or evidence. But I invite 
Binmore to read Volume 3, Bourgeois Rhetorics, which will deal with such matters in more detail. When I get to that book I promise to read his own work on justice, which I am sure is like all his work very clever. He is offended I did not cite his work in the present book (though that I cite so many people is also irritating to him; either way).

(4) Binmore says that Rawls did not try to pull a decently ethical theory out a Paretian hat. Again the point is tangential to the present volume, but yes, he did. One may read more on the subject in my piece on Hobbes, Nussbaum, Rawls and Buchanan, which will be part of Volume 3, and is available on my website. ${ }^{7}$ The 'distributional issues', which Binmore correctly notes are what The Theory of Justice is all about, arise you may recall from a constitutional decision by a supposedly rational Max Uer behind a veil of ignorance about her place in the implied distribution. Binmore and I would I think join in complaining about Rawls' argument that he assumes without much argument a maximin utility function, which is what forces his distributional result. But anyway my account of Rawls, even as approaching a libertarian political position (as serious readers of Rawls beyond The Theory of Justice admit, or are reluctant to admit but know), is routine and correct.

So let's see: out of four counts Binmore gets one half right. One out of eight. Binmore surely selected what he thought were the most egregious of my 'errors', about which he was absolutely sure he was correct. One might infer from his test therefore that I am remarkably reliable, at any rate for someone who ventures to bring more than a narrow version of 'science' to bear on describing human life, and that Binmore himself is remarkably unreliable.

And so he is throughout. He says for example that my reading of van Gogh's life is disgracefully 'typical' of my mode of operation in depending on 'obscure authorities with off-the-wall opinions'. His opinions on van Gogh appear to be based on the usual Romantic myth, such as Lust for Life (the movie - not anything so scholarly as the novel). Binmore is absolutely sure that he, having actually seen Kirk Douglas cut off his ear, knows more about van Gogh than I or the serious historians of art do. He doesn't know that my anti-Romantic reading is the commonplace consensus of the scholars, and is nothing like obscure or off-the-wall. If he had listened humbly, as we all should, he could have learned it from the book.

In parading his atheism he criticizes me for 'parading' my Christianity, which he calls 'religious fairy stories', with which he 'has no truck'. There's an open, well-stocked mind. But the Christian theme in the book, though not its main point, is strictly relevant, since virtue ethics was developed among Christians (and among some pagans and among Confucians, too, as I explain). Binmore doesn't actually know all that much about Christianity, or Judaism, or any other of the fairy stories, though he knows what he doesn't like. He thinks for example that the prohibition of graven images is quite irrelevant to my discussion of the sin of pride, and criticizes me for bringing it up. It is part of his theme that I do a lot of irrelevant exhibiting of erudition. Binmore appears not to have ventured into theology or biblical criticism - an ignorance that is pretty common among people who parade their atheism. Like Christopher Hitchens declaring that God is not great or Richard Dawkins that God is a delusion, they haven't bothered to learn anything about what they are attacking.

The secular point, my dear Ken, of not worshipping other gods before The God (al Lah) is to discipline human pride, which tends otherwise to put little moi in the place of God. 
Moi is not a god suitable for human virtue. As I say in the book, the worship of God or Science or whatever will recommend especially the virtue of listening, really listening. ${ }^{8}$ The proud physicist or economist puts her soul in danger if she elevates her brilliant career in string theory or game theory over the facts of God's world. Thus said St Thomas Aquinas. We Christians call it 'humility', and many people have noted that it is the chief virtue of a serious scientist, humility before Nature or Society. Thus Iris Murdoch, the philosopher and novelist (sorry to stray from Science, dear): 'Humility is not a peculiar habit of self-effacement, rather like having an inaudible voice. It is selfless respect for reality and one of the most difficult and central of all virtues'.

Binmore indulges in a proud, indignant defense of the conventional wisdom of atheism. He believes, for another example, that Faith is 'willfully acting as though something were true without any evidence'. It is the usual, ignorant atheist's take on a great virtue - which I explain at length can be given an entirely secular backing, too, as the virtue of identity and integrity. Faith is not 'willful' or 'without any evidence', as Binmore can learn if he will but look humbly into, say, Alvin Plantinga's trilogy on warrants, the last of which (Plantinga 2000) concerns the warrants for Christian belief, or into St Paul and St Augustine and above all St Thomas. Binmore hasn't cracked a book on theology, hasn't listened to the other side, and so again has no idea what he is attacking.

On this point as on most others he appears not to have cracked my book either. I have a long discussion (pp. 168-171) about why André Comte-Sponville (1996), another atheist uncomfortable with faith and hope, is mistaken. How do I know Binmore didn't read the pages? Because there (p. 170) and elsewhere I make the routine argument that Binmore trots out triumphantly, that hope is dangerous in the form of utopianism. Yes, it is. But he shows in his prideful declaration that he thinks I don't make the point. A little test of scholarly faithfulness in book reviewing, eh? Buzz!

Binmore allows himself side comments meant to display his wit, apparently because he regards the book as some sort of evening's entertainment, not the way, for example, the political philosopher Alan Ryan (2006) regarded it in the New York Review of Books. So he feels justified to reply in witty kind. For example, he declares that the virtues are seven 'for presumably the same reason that there are seven dwarfs'. My, my, how amusing. What a clever cultural reference. Cool. Evidently Binmore did not read much of the book, because much of it is devoted to explaining in detail why the seven arose in Western thought, how they have parallels in Eastern thought, how they fit with modern psychological studies, and so forth. This for hundreds of pages, which Binmore missed.

My fault, though: if an author can't hold a reader's attention any better than that, she is to blame.

So Binmore the mathematician-economist, quite unlike Graafland the economisttheologian, has done a sneering, silly review because he has not read the book with the virtue of humility. He has not listened, really listened, and so he hasn't learned, or considered seriously whether his own ideas are mistaken. Marianne Ferber's review is another illustration of the usefulness of thinking in terms of the virtues and vices. She, too, lacks humility, and indulges additionally in the sin of anger.

Ferber starts out by instructing me a little on the idiomatic use of English. But immediately she turns to her main and persistent anger, that I presume to defend capitalism, along with those other 'University of Chicago types'. And she is outraged that even politically acceptable people like Martha Nussbaum or Benjamin Friedman found merit in the book. You can see the Stalinist line. Either you are anti-capitalist and her friend, or pro-capitalist and her enemy. 
Ferber's text is jammed with 'ostentatious display[s] of learning, obviously intended to dazzle readers' about Enron and food deserts and the Tenth Commandment. Yet by her own admission she has not actually read the book, and so she gets my views wrong. For example, I am just as appalled as she is by food deserts in African-American neighborhoods. Our only difference is that I do not think corporate irresponsibility is to blame, since after all there once were plenty of (corporate) grocery stores there, and still are in Hispanic neighborhoods. She accuses me of 'ignoring' the military-industrial complex. Wrong, as she would know if she had troubled to read. The Bush administration is devoted to the military-oil-industrial complex, but I join Adam Smith in viewing such complexes as contrary to the simple and obvious system of natural liberty. They are government-sponsored monopolies - which the Bush administration is indeed enthusiastic for - not an ethical capitalism such as Smith and Milton Friedman and James Buchanan and John Rawls and I would favor. If Ferber had done more than 'skim' the book she would have learned this.

The Bush administration, she thinks, is 'as dedicated to unfettered private enterprise as any the world has seen'. Not in my view, on display in the book: post-War Hong Kong under the British would be a much better example, with people in poverty raised to a high standard of living in two decades by the working of an evil, unrestrained capitalism. She accuses me of 'making light of our environmental problems'. No, especially problems of air quality. She thinks I confine the virtue of courage to masculine and battlefield instances. I do not, and it is merely careless of her to say so. The book has two chapters devoted specifically to analyzing from a feminist perspective the trouble with defining courage in military ways alone. She thinks I define 'hope' as mindless optimism (which, by the way, is another of the adolescent misunderstandings of Christian virtues in the atheist party line). No, hope is having a project. Therefore when one is without medical care, hope is not falling into inactive despair but seeking a course of action to try, perhaps unsuccessfully in a world of bitter scarcity, to get it stealing the medicine from the pharmacist to save one's husband, to take a famous example.

Ferber doubts the 'extravagant' claim that capitalism has improved equality over the long run by noting that in the short run equality has worsened in the US. Her argument is illogical, in appealing to the short run to reject a claim about the long. But she has apparently not read the history - the 'extravagant' claim I make is a routine point among economic historians. And to speak of the short run she does not realize that inequality associated with the intersection of higher education and education-loving changes in the economy affects most developed countries - not merely under the Bush administration, which she and I join in detesting. ${ }^{10}$

Unlike Marianne about her left liberalism, I'm not dogmatic about my libertarianism, no more than about my Christianity. I'll not cast you into Hell if you are not a progressive Anglican like me, no more than if you believe that health insurance for everyone or regulation of taxi cabs are good ideas. But then I expect you, like Graafland is, to be open to worrying with me that the health insurance will be corrupted by hospital companies, as it is in Chicago, or that the taxi regulation will be corrupted by gangsters, as it is in Amsterdam. I expect you to listen, as I listen to you.

I have known Marianne casually for quite a while - she is a leader in feminist economics, and I have in a minor way been involved in that movement (for example, I contributed to the first edition of one of her edited books on the subject). But the contrast with some of the other leaders in feminist economics, such as Barbara Bergmann, Nancy Folbre, Susan Feiner and Diane Strassmann, is sharp. Though none is anything like 
a University of Chicago type, they will with courtesy, and with the hope of improving their own arguments, listen and consider.

Nancy Folbre, for example, has half persuaded me that the centralized French system of early childcare has merits. Susan Feiner has more than half persuaded me that Samuelsonian economics is masculinist. ${ }^{11}$ When Barbara Bergmann met me in Mexico City during one of our annual meetings of the International Association for Feminist Economics she immediately insisted that we talk at length about the welfare state, because standing there before her was a certified University of Chicago type and she wanted to improve her own arguments by listening to and arguing with what an opponent had to say. Since she knows embarrassingly more about the welfare state than I do, I learned a great deal more from the conversation than she did. It's that way with intellectual trade, if you will but listen. Marianne, on the other hand, doesn't want to listen to anyone. She has gotten the party line. Therefore, why bother? One hopes that she will not succeed in setting the tone for feminist economics.

What can we learn about the methodology of economics from all this sound and fury?

For one thing, as we see here, the arguments against capitalism have not been thought out in a self-critical fashion. It is surprising, because since 1848 the clerisy of Europe have written many thousands of books attacking the system they hate. You would think they would have made some progress. People handle over and over again their worry beads of 'the highly unrealistic premise that all markets are perfectly competitive' (Binmore) or 'capitalism causes inequality of real comfort' or 'capitalism erodes community', but they don't scrutinize them. ${ }^{12}$ I wish they would, which is why I wrote The Bourgeois Virtues. Maybe the numerous enemies of capitalism are right. Maybe I am wrong in what I claim in the book. I'm willing to entertain the hypothesis. After all, when I was a Marxist, and then a Galbraithian Democrat, I believed as they do. But I'd like to see the evidence and the arguments, beyond sneering and indignation and the handling of unscrutinized worry beads.

And for another, we learn this: the sole methodological principle that we should abide by is to listen and learn. That is, economic methodology is not a matter of following the rules of Binmore's 'science' or Ferber's party line. It is about ethics. It is a matter of saying courageously what you think, then temperately listening to what others say, and allowing yourself in justice to be influenced in your thinking by what they say, keeping faith with the character of the true scholar. Science is made, I say, from courage and temperance and justice and faith. Such are the ethical principles followed, on the evidence I have seen, by Johan Graafland, Herbert Gintis, Robert Fogel, Martha Nussbaum, Robert Nozick, Barbara Bergmann. All these people have radically changed their minds about some things, because they have listened. Ken Binmore and Marianne Ferber do not follow The Listening Principle.

The principle was articulated long ago by Amélie Oksenberg Rorty, a brilliant and useful philosopher/anthropologist (Amélie decided age 53 or so that she needed to know more about how people actually lived in order to do ethical philosophy correctly: so she pursued a second Ph.D. in anthropology; thus the virtue of 'recognizing no boundaries at all'). What is crucial in our intellectual and political and social lives, she wrote (1983, p. 562), is

our ability to engage in continuous conversation, testing one another, discovering our hidden presuppositions, changing our minds because we have listened to the voices of our fellows. Lunatics also change their minds, but their minds change with the tides of the moon and not because they have listened, really listened, to their friends' questions and objections.

Words to live by, and to do science and scholarship by. 


\section{Notes}

1. McCloskey (2006a).

2. Landes (2006, p. 9).

3. McCloskey (2008a).

4. Nozick (1974, p. 42).

5. Nozick (1989, p. 102).

6. Feinstein (2007, pp. 133, 134, 150).

7. At deirdremccloskey.org. A shorter version is (2006c), and still shorter McCloskey (2006d).

8. McCloskey (2006b, p. 185).

9. Murdoch (1967, p. 95).

10. Goldin and Katz (2008).

11. McCloskey (2008b).

12. A recent exception is Stephen Marglin (2008); and for an old an admirable one, Baran and Sweezy (1966). Not that they are right. But they are serious scientists.

\section{References}

Baran, P.A., and Sweezy, P.M. (1966), Monopoly Capital: An Essay on the American Economic and Social Order, New York: Monthly Review Press.

Bayle, P. (1697), Dictionnaire historique et critique, Rotterdam: Leers [2nd ed. 1702].

Comte-Sponville, A. (1996), A Small Treatise on the Great Virtues, New York: Henry Holt [C. Temerson, trans., 2001, Metropolitan/Owl Books].

Feinstein, A. (2007), After the Party: A Personal and Political Journey Inside the ANC, Johannesburg and Cape Town: Jonathan Ball.

Goldin, C., and Katz, L.F. (2008), The Race Between Education and Technology, Cambridge, MA: Harvard University Press.

Henrich, J., Boyd, R., Bowles, S., Camerer, C., Fehr, E., and Gintis, H. (2004), Foundations of Human Sociality: Economic Experiments and Ethnographical Evidence From Fifteen SmallScale Societies, Oxford: Oxford University Press.

Kolko, G. (1965), Railroads and Regulation, 1877-1916, Westport, CT: Greenwood.

Landes, D.S. (2006), Dynasties: Fortune and Misfortune in the World's Great Family Businesses, London and New York: Penguin.

Lennon, T.M. (2003), 'Pierre Bayle', in The Stanford Encyclopedia of Philosophy, http://plato. stanford.edu/entries/bayle/\#Bib.

Marglin, S.S. (2008), The Dismal Science: How Thinking Like an Economist Undermines Community, Cambridge, MA: Harvard University Press.

McCloskey, D.N. (2006a), 'Humility and Truth', Anglican Theological Review, 88(2), $181-196$.

(2006b), The Bourgeois Virtues: Ethics for an Age of Commerce, Chicago: University of Chicago Press.

(2006c), 'The Hobbes Problem From Hobbes to Buchanan', First Annual Buchanan Lecture, George Mason University, 7 April. http://www.gmu.edu/centers/publicchoice/pdf\%20links/ dpaper4706.pdf.

- (2006d), 'Hobbes, Nussbaum, and All Seven of the Virtues', Development and Change, $37(6), 1309-1312$.

(2008a), 'Adam Smith, the Last of the Former Virtue Ethicists', History of Political Economy, 40(1), 43-71.

(2008b), 'Mr. Max and the Substantive Error of Manly Economics: A Comment on: Christina Jonung and Ann-Charlotte Ståhlberg, "Reaching the Top: On Gender Balance in the Economics Profession"', Econ Journal Watch, 5(2), 32-35.

Murdoch, I. (1967), 'The Sovereignty of Good Over Other Concepts', Leslie Stephen Lecture, in The Sovereignty of Good, pp. 77-104 [London and New York: Routledge, 1970, 1985].

Nozick, R. (1974), Anarchy, State, and Utopia, New York: Basic Books. (1989), The Examined Life: Philosophical Meditations, New York: Simon \& Schuster.

Plantinga, A. (2000), Warranted Christian Belief, New York and Oxford: Oxford University Press.

Rorty, A.O. (1983), 'Experiments in Philosophical Genre: Descartes' Meditations', Critical Inquiry, 9(March), 545-565. 
Ryan, A. (2006), 'Is Capitalism Good for You?' [Review of The Bourgeois Virtues], New York Review of Books, 21 December.

Willard, D. (2003), 'Hume's Remarks About 'Monkish Virtue: Comments on Papers by Davie and King', Hume Society Meetings, Las Vegas. http://www.dwillard.org/articles/artview.asp?ar $t I D \&=93$. 
Copyright of Journal of Economic Methodology is the property of Routledge and its content may not be copied or emailed to multiple sites or posted to a listserv without the copyright holder's express written permission. However, users may print, download, or email articles for individual use. 